\title{
The Duality Conception on Ngaju Dayak Thoughts in Central Kalimantan
}

\author{
Imam Qalyubi \\ State Islamic Institute Palangka Raya \\ imamqalyubi@yahoo.com
}

\begin{abstract}
This paper attempts to reveal the duality conception in Ngaju Dayak culture in Central Kalimantan. The duality or in another discipline such as linguistics refers to binary opposition. The emergence of the duality terms initially refers to cosmological system, thatis the universe has a dichotomous dimension. This cosmic universe consists of two oppositional components which are essentially complementary and unified. In Indonesia the duality conception as discussed in this paper is basically not merely within the Ngaju Dayak culture, but it also can be found in other cultures such as Javanese culture as well as Banjarese culture. For instance, Javanese culture has the duality concept between the sky, that is represented as father, and the world is represented as motherland. While in Banjarese culture, there is the duality between tubaniyah (amniotic fluid) with tambuniyah (placenta). In revealing the duality conception, this study applies the structural method, developed by Levi Strauss.
\end{abstract}

Keywords: Duality, Conception, Ngaju Dayak, Cosmology, and Central Kalimantan

\section{INTRODUCTION}

The duality conception in some disciplines is not completely a new topic. If we read some books of philosophy and sociology; then we could easily find various debates regarding the concept of duality from Rene Descartes, Immanuel Kant, to Karl Marx [1], [2]. In the Greek philosophy era, the duality concept initially emerged when the Pythagoras philosophers made the duality conception between good and evil, love and hatred, one and many, etc. Philosopher CristianWolf highlighted "the duality is the dualist those who are living the material of both material and immaterial substances" [3].

If refered to various sources of reference, the concept of duality is derived from the cosmological paradigm of seeing that all the realities existing in the world are always associated with the nature and structure of the universe [4]. The structure of the universe is commonly described as the top and bottom relationship or also called as the sky and the earth connection where the relationship between them is opposite or dichotomous. If partially observed, both appear opposite, but they are essentially a complementary when considered more deeply. This cosmological concept is the oldest concept of knowledge that ever existed as the knowledge of the universe is the beginning of human knowledge

In Nusantara tradition the duality concept has become the most important part in both spiritual and cultural aspects. Robert Dick Reid underlined that the concept of duality in the archipelago spiritualties in the ancient timehada great influence to spiritualism in Africa [5]. The concept of the spiritual duality in the archipelago is phallus and yoni. The phallus represents a male genital while yoni is a woman's genital representation. In the archipelago, phallus and yoni is a form of duality showcasing different but in fact, they are unity.The unification between them is a symbol of perfection or authenticity.

In the modern science the concept of duality can easily be identified in linguistic studies initiated by modern linguistic figures, such as Ferdinand de Saussure in the early 19th century. He offers an idea in which both are always contrasted or dichotomous, later known as binnary opposition. They are langue and parole, siginifiers and signified, paradigmatic and syntactic, as well as synchronic and diachronic. The term binnary opposition was popularized Saussure's book, Course in General Lingusitics, published in 1916 [6], [7]. Saussure (1959) said this kind of binnary opposition is called "not distinct but distinct only". Later, Thebinnary opposition concept wasdeveloped and repopularized by structural anthropologist Levi Strauss [8].

In relation to the various elaborations of the dualities described above, this paper would like to discuss the duality found in the Ngaju Dayak mindset in Central Kalimantan. In this paper discussion,s ome primary and secondary documents were used as references as written by Han Scharer [9] entitled "Ngaju Religion : A Conception of God among a South Borneo People" [10].Other refererences were included including "The Dayak Trust in Land Landak and Tayan", by Mikhail Cooman in his book entitles "Manusia Daya" and the local Borneo author Amir HasanKiaiBondan [11] entitled "Suluh Sedjarah Kalimantan" as well as some other related books. 


\section{METHOD}

The structural method developed by Levi Strauss was implemented in this research. The method was affected by the linguistic way of thinking initiated by Ferdinand de Saussure. In linguistics, to reach a mechanism of structure, it is necessarily essential to analyze the phonema in opposition with otherphonemes so itcould be formed as binary opposition [12]. It was from this early concept of the opposition, then Strauss developed it into anthropological studies which later were known as structural anthropology. The essence of this structural study wasto highlight every culture has a universal structure but the forms could be different depending on the community social context. Structuralism conveyed that a certain culture of a particular society has a typical patternalso owned by other cultures. However, the society might be not aware of it.

\section{DISCUSSION}

In Ngaju Dayak social life there are various concepts of duality, covering both spiritual and social aspects. The following discussion will elaborate further the concept of duality in Ngaju Dayak culture viewed from various aspects.

\section{The Ngaju Dayak Duality Concept on Spiritualism Aspect}

After reviewing several sources and doing direct observation, the researcher found various patterns regarding Ngaju Dayak society spiritualism concept, particularly those embracing the local religion of Kaharingan. They have a duality conceptwhich was similarly found in the Fridolin Ukurnotes [13].That wasNgaju people believe there are two supreme Gods, which is essentiallyjust one, which are distinguishablebut not separable. Each God, according to Ukur, has different nature and dwelling. In fact,they are supplementary, complementary and compensatory [13]. In addition to Hans Scharer's view, a British missionary, who was in charge of Borneo at that time, also found the same findings that he documented in his book "The Conception of God Among A South Borneo People" of 1963. To see more clearconcept of duality on the spiritual aspect of Ngaju Dayak culture in Central Kalimantan, notice the following examples:

\section{Upper World God}

$\begin{array}{lc}\text { 1. Mahatala } & >< \\ \text { 2. Tingang } & >< \\ \text { 3. RajaTontong Matanadau }>< \\ & \\ \text { 4. Spear } & >< \\ \text { 5. White } & ><\end{array}$

\section{Under World God}

PutirSelongTamanang Tambon

Bawin Jata Balawang Bulau (Female)

Cloth

Red Mixed Yellow
From some examples of the divine duality concept in the Ngaju Dayak above, it seems that Gods in the collectives memory of Ngaju Kaharingan Dayak were manifested in multiple representations where each is a pattern of contradictions or dualities, yet they are essentially one unity which was inseparable. The duality concept in Dayak spirituality aspect is so diverse and full of metaphorical and beautiful phrases. In general, the concept of duality in the spiritual Ngaju Dayak aspect is expressed with sangiang language which is the topranking language because it is only used in spells or in Panaturan, the Kaharingan holy book.

In addition to the duality concept of spiritualism aspect in Ngaju Dayak, the paper would also underline the socio-cultural aspect

\section{The Ngaju Dayak Duality Concept on Social Culture Aspects}

1. Ngaju (upstream) vs. Ngawa (downstream)

2. Ngambu (land) vs. Liwa (sea)

3. Land (city) vs. Trunk (river)

4. Kabelomandau (sunrise vs. Kabelepandau (sunset)

5. Traditional Judge (Ellected by god) vs. Damang Adat (elected by community)

The examples above clearly shows that the Ngaju Dayak culture believed the different spatial dimensions of the general culture particularly in Indonesia. The Ngaju Dayak culture commonly does not recognize the concept of points of compass such as east, west, north and south. Instead, Ngaju people implemented the concept of space dimensions such as upstream and downriver and overland and sea as well as land (city) is contrasted to water (below). The existance of the concept is based on the Ngaju Dayak society dwelling in the river area. However, nowadays, many Ngaju Dayak people live in urban areas far away from the river.

To display up and down in the Ngaju Dayak, it was also found the use of cableomanandau or a place where the sun rises, opposed to the orau or dark day or sunset. In addition, there is also a conclicting issue regarding the judges. A God representing a God is called as an adat judge and a human judge is called a customary damang. They are disputed because the Judge of God, according to their belief, is directly chosen by God. On the other hand, the damang adat is the judge who is chosen by the people's agreement.

That is clear that the concept of duality is manifested in spiritualism and socio-culture aspects of life in Ngaju Dayak culture. It is believed to be also found in other aspects such as politics and economics. Nevertheless, it certainly requires more comprehensive research. 


\section{CONCLUSION}

The study clearly underlined that Ngaju Dayak culture in Central Kalimantan has a duality conception. The concept of duality was mapped into two areas, namely spiritual and the socio-cultural. When seen from the structural theory view, it was clear that the existence of the duality concept in the Dayak culture substantially applies to other cultures but with different forms. For example, it can be seen from the concept of duality in the divine aspect. In Ngaju Dayak mindset, particularly Kaharingan adherents, that Godhas the duality concept. The depiction of the divinity of Mahatalaand Putir Selong Tamanangis the representation of the totality of divinity, that is the ruling God in the upper realm and that is represented by male. On the other hand, Putir Selong Tamanang is represented as female who dwells in the underworld.

The divine duality is not a separated distinction that stands at the individual poles. However, the difference shows an inseparable unity concept. It means the differences are complementary, and united each other. In other words, the presence of one is not complete yet without the presence of the other.

The duality and divine conception in the Ngaju Dayak culture were also identifiable in the socio-cultural aspects in Dayak community. It related to the wind direction in which they do not recognize the west, east, south and north directions. Instead, they use the ngaju (upstream), ngawa (downstream), netting (land) and liwa (sea). They also sometimes use a dash andau (sunrise) or cable and andau (sunset). Regarding the legal aspect in Ngaju Dayak culture, there are differences or contradictions between judges who are directly elected by God, called adat(culture) judge and a judge pointed out by the community referred to as a customary demang. The study discussed briefly the various concepts of duality in the aspects of spirituality and socio-culture owned in the Ngaju Dayak culture. To be more thorough in uncovering the duality concepts, of course, it is required broader and deeper study about the topic.

\section{REFERENCES}

[1] J. Siswanto, "Western Metaphysical Systems", 1998.

[2] Y. Anwar \&Adang, "Sociology for Universities", 2013

[3] H. F. Zarkasy, 2008, "Dualism", Journal of Islam, VolIII / 2008 / no.3.

[4] A. Sukadana, "Anthropo Ecology", 1983.

[5] R, D. Reid, "The Influence of Nusantara Civilization in Africa: Marine Exploration", 2008.

[6] F. de Saussure, "Course in General Lingusitics", 1959.

[7] T. W.Gordon, "Saussure for Beginners", 2002.

[8] S.H.A. Son, "Levi-Stauss Structuralism": Myths and Literary Works ", 2001.

[9] H. Scharer, "The Conception of God Among A South Borneo People", 1963.

[10] M.C Schadee, "Dayak Trust in Land of Landak and Tayan", 1979.

[11] M. Cooman, "Human Power First, Now, Future", 1979.

[12] A. H.K. Bondan, "Seduh History of Borneo", 1953.

[13] Strauss, Claude Levi, Myths and Meaning: Dismantling Cultural Codes, Tackling: Left Margin, 2005.

[14] Measure, Fridolin, 1992, "The Religion of the Dayak Tribe:" Hindu Kaharingan ", In the 1992/2/1993/1 THESE REVIEWER Magazine: XVII / 2 / XVIII / 1, Published by the Council for Research and Development of Fellowship of Churches in Indonesia. 